\title{
FOREGROUNDING SOCIO-ECONOMIC RIGHTS IN TRANSITIONAL JUSTICE: REALISING JUSTICE FOR VIOLATIONS OF ECONOMIC AND SOCIAL RIGHTS
}

\author{
Amanda CAHILl-RIPLEY*
}

\begin{abstract}
:
Transitional justice has traditionally ignored or sidelined violations of economic and social rights, focussing on violations of civil and political rights as the primary grave human rights violations to be addressed when seeking justice for past atrocities. This paper explores the omission of these rights from the field and uncovers the shortcomings of such an approach. It will argue that there is a need for transitional justice to address both deliberate violations of economic and social rights resulting from conflict or repression, but also structural violations which have acted as root causes of conflict within the State. It is submitted that past experiences of prosecutorial and restorative justice illustrate that violations of economic and social rights have been acknowledged as background information rather than primary concerns for transitional justice. In conclusion it is contended that economic and social rights need to be brought to the foreground of transitional justice processes in order to ensure effective transitional justice which reflects the needs and rights of the local population, and addresses the root causes of conflict, thus preventing conflict reoccurring around the same sources. The inclusion of economic and social rights concerns within transitional justice mechanisms will therefore contribute to a more holistic and inclusive transitional justice process.
\end{abstract}

Keywords: conflict; economic, social and cultural rights; international criminal law; peacebuilding; social justice; structural violence; transitional justice; truth commissions

Amanda Cahill-Ripley is Lecturer in Law at Lancaster University, UK and Visiting Lecturer in Human Rights Law at the University of Bergen, Norway. Contact a.cahill@lancaster.ac.uk. 


\section{INTRODUCTION}

Transitional justice has traditionally ignored or sidelined violations of economic and social rights, focussing almost entirely on violations of civil and political rights as the primary grave human rights violations to be addressed when seeking justice for past atrocities. ${ }^{1}$ Whilst selected authors have addressed the at times conflicting aims of 'justice' and 'peace', ${ }^{2}$ very little attention has been given to the consequences for peace and justice if violations of economic and social rights are either completely ignored, are relegated to secondary concerns or are presented as 'background' information, that is information which is setting the context for what are perceived as more serious violations of civil and political rights. Whilst violations of economic and social rights may seem to be of a lesser gravity than those of civil and political rights (such as the right to life and freedom from torture), socio-economic rights violations can constitute gross human rights violations. Some examples may include the burning and destruction of homes and crops; the poisoning of water; forced evictions; deliberately induced starvation and displacement leading to lack of housing, water and food, subsequent ill health and disease, lack of education and employment and in the worst cases human deaths.

Moreover, such violations may be more widespread and systematic. For instance, in the conflict in Timor-Leste it was noted that far more people were affected by economic and social rights violations than civil and political rights violations. ${ }^{3}$ The displacement of people from their villages, farms and traditional settlements resulted in severe violations of the rights to food, health, housing, education, self-determination

$1 \quad$ Office of the High Commissioner for Human Rights, Analytical study on human rights and transitional justice (United Nations 2009) A/HRC/12/18 para 59; International Council on Human Rights Policy, Negotiating Justice? Human Rights and Peace Agreements (International Council on Human Rights Policy 2006) 101; Lisa Laplante, 'Transitional Justice and Peace Building: Diagnosing and Addressing the Socioeconomic Roots of Violence through a Human Rights Framework' (2008) 2 The International Journal of Transitional Justice 331, 333; L. Waldorf, 'Anticipating the Past: Transitional Justice and Socio-Economic Wrongs' (2012) 21(2) Social and Legal Studies 171, 173.

2 Hurst Hannum, 'Peace versus Justice: Creating Rights as well as Order out of Chaos' (2006) 13(4) International Peacekeeping 582; N. Roht-Arriaza and J. Mariezcurrena (eds), Transitional Justice in the $21^{\text {st }}$ century - Beyond Truth versus Justice (Cambridge University Press 2006); I. Zartman and V. Kremeniuk (eds), Peace Versus Justice: Negotiating Forward-and Backward-looking Outcomes (Rowman and Littlefield 2005); Ellen L. Lutz, Eileen F. Babbitt, and Hurst Hannum, 'Human Rights and Conflict Resolution from the Practitioners' Perspectives' (2003) 27(1) The Fletcher Forum of World Affairs 173; C. Lekha Sriram and S. Pillay (eds) Peace Versus Justice?: The Dilemmas of Transitional Justice in Africa (James Currey Publishers 2010); P. Schulz, Peace Versus Justice?: The International Criminal Court (ICC) in Africa (VDM Publishing 2011).

3 The Commission for Reception, Truth and Reconciliation in Timor-Leste, Chega! The Report of the Commission for Reception, Truth and Reconciliation in Timor-Leste (CAVR) (Commission for Reception, Truth and Reconciliation 31 October 2005) Executive Summary 74; ch 7.9: Economic and Social Rights. 
of resources and freedom of movement. ${ }^{4}$ These economic and social rights violations were directly attributable to the conflict.

In addition, violations of economic and social rights can act as conflict triggers. ${ }^{5}$ As the International Council on Human Rights Policy notes, '[...] socio-economic issues often lie at the core of conflicts, and are particularly implicated in the transitional period, when reconstruction of war-torn societies must take place'. ${ }^{6}$ As such, ignoring violations of such rights is a risk both to the peace process and the effectiveness of justice mechanisms during transition. The Editors of The International Journal of Transitional Justice note,

Our preoccupation with justice after civil upheaval seems to outstrip our attention to preventing or attending to the systematic injustices - economic, social and political - that fuel the causes that erupt into paroxysms of violence. We have an international criminal court to prosecute war criminals, yet millions of civilians are deprived of adequate water, nutrition and healthcare [...]. There is a conspicuous absence of international accountability for these injustices. ${ }^{7}$

This paper will explore this omission of economic and social rights from transitional justice. It will examine possible reasons for the limited attention or indeed exclusion of these rights and uncover the shortcomings of such an approach. It will investigate whether there is a need to redefine transitional justice, to embrace a holistic conception of justice ${ }^{8}$ inclusive of ideas of social justice including therefore justice for violations of economic, social and cultural rights. It will argue that the recognition of these rights within transitional justice mechanisms will make transitional justice more effective in responding to the needs of the people, firstly by seeking remedy for deliberate and direct violations of economic and social rights but also by addressing violations of these rights which have acted as root causes of conflict, thus helping to prevent conflict reoccurring around the same sources. Further, if human rights are truly indivisible and interdependent violations of civil and political rights cannot be addressed effectively in times of transition unless corresponding and related violations of economic and social rights are also addressed. The inclusion of economic and social rights concerns within transitional justice mechanisms will therefore contribute to a more holistic and inclusive transitional justice process.

\footnotetext{
$4 \quad$ Ibid.

5 Office of the High Commissioner for Human Rights (n 2); E. Schmid, 'Liberia's Truth Commission Report: Economic, Social and Cultural Rights in Transitional Justice' (2009) XXIV Praxis - The Fletcher Journal of Human Security 5, 6; S.C. Agbakwa, 'A Path Least Taken: Economic and Social Rights and the Prospects of Conflict Prevention and Peacebuilding in Africa' (2003) 47(1) Journal of African Law 38, 40; Laplante (n 1) 334-335.

6 International Council on Human Rights Policy (n 1) 101.

7 Editorial, (2012) 6(1) International Journal of Transitional Justice (IJTJ) 6.

8 A. Boraine, 'Transitional Justice: A Holistic Interpretation' (2006) 60(1) Journal of International Affairs 17, 17.
} 
The definition of transitional justice is contested: One frequently quoted definition is provided by Roht-Arriaza, who defines transitional justice as 'a set of practices, mechanisms and concerns that arise following a period of conflict, civil strife or repression, and that are aimed directly at confronting and dealing with past violations of human rights and humanitarian law. ${ }^{9}$ However, as Arbour argues,

Transitional justice must have the ambition to assist the transformation of oppressed societies into free ones by addressing the injustices of the past through measures that will procure an equitable future. It must reach to - but also beyond - the crimes and abuses committed during the conflict that led to the transition, and it must address the human rights violations that pre-dated the conflict and caused or contributed to it. With these aims so broadly defined, transitional justice practitioners will very likely expose a great number of discriminatory practices and violations of economic, social, and cultural rights. ${ }^{10}$

With such variety in the interpretation of what transitional justice is, the first section of the paper will examine current definitions of transitional justice and explore the reasons why economic and social rights have been largely excluded from the field. This will include an investigation of the notion of justice inherent in transitional practices. Second, the author will examine previous examples of transitional justice mechanisms to explore how they have dealt with violations of economic and social rights. This will include consideration of prosecutorial methods such as international tribunals and the International Criminal Court (ICC) and an investigation of restorative methods such as truth and reconciliation commissions. Cases explored include South Africa, Liberia, Sierra Leone and Timor-Leste. These particular cases have been selected as limited examples where the Commissions have considered economic and social rights in some way. Finally there will be a discussion on how to expand and develop the concept and practice of transitional justice to incorporate these rights, including offering proposals for improvement drawn from good practice and identifying continuing challenges to this process.

\section{WHY IS THERE A LACK OF ECONOMIC AND SOCIAL RIGHTS WITHIN 'TRADITIONAL' TRANSITIONAL JUSTICE?}

\subsection{THE 'NARROW’ DEFINITION OF TRANSITIONAL JUSTICE}

It is submitted that 'Traditional' transitional justice consists of prosecutorial justice, such as tribunals and trials, where the focus is on establishing accountability,

\footnotetext{
9 Roht-Arriaza and Mariezcurrena (n 2) 2.

10 L. Arbour, 'Economic and Social Justice for Societies in Transition' (2007) 40(1) International Law and Politics 1, 3.
} 
responsibility and punishment for crimes. It also consists of mechanisms of restorative justice, although the concept of 'restorative justice' is limited in this discussion to truth and reconciliation commissions. ${ }^{11}$ This mechanism focuses on the idea of 'truth telling' as allowing reconciliation. The above mechanisms are judicial or quasijudicial and their primary mandate is to deal with mass and grave violations that have occurred during the conflict in question. However, very little consideration has been given to economic and social rights within these mechanisms. There are several reasons for this. One reason for the omission (or very limited consideration) of such rights to date is simply because economic and social rights are not seen as within the remit of transitional justice. This argument is dependent on how transitional justice is defined and what the role of transitional justice is believed to be. Transitional justice has many definitions, ${ }^{12}$ and arguments have been put forward for it to include, for instance, justice for economic crimes, development concerns and local and community-based approaches to justice and reconciliation. ${ }^{13}$ However, it remains overwhelmingly concerned with criminal prosecutions and truth commissions in relation to civil and political rights violations. Olsen defines transitional justice as 'the array of processes designed to address past human rights violations following periods of political turmoil, state repression, or armed conflict'. ${ }^{14}$ Olsen notes 'Human rights violations are defined as extrajudicial killings, disappearances, torture and arbitrary arrest and imprisonment' only. ${ }^{15}$ Two significant factors are apparent with this definition. First, the focus is purely on past violations, and, second, on violations of civil and political rights alone - not economic and social rights. This definition could be considered illustrative of the prevalent traditional concept of transitional justice which has dominated the field until recently. ${ }^{16}$

\subsection{ECONOMIC AND SOCIAL RIGHTS - NOT LEGAL RIGHTS}

A further reason why transitional justice both in theory and in practice has tended to omit or severely limit consideration of economic and social rights is the familiar

11 Other mechanisms such as reparations and institutional reform can be considered a part of restorative justice. For example see T. Olsen, L. Payne and A. Reiter, Transitional Justice in Balance - Comparing Processes, Weighing Efficacy (US Institute of Peace Press 2010) 12. However, in terms of traditional transitional justice, the focus has been very much on truth commissions.

12 For example see International Centre for Transitional Justice (ICTJ), Fact Sheet 'What is Transitional Justice?' (ICTJ 2009) at <http://ictransitional justice.org/about/transitional-justice>, last accessed 14 June 2013; P. Arthur, 'How Transitions Reshaped Human Rights: A Conceptual History of Transitional Justice' (2009) 31(2) Human Rights Quarterly 321; C. Bell, 'Transitional Justice, Interdisciplinarity and the state of the "Field" or "Non-Field"' (2009) 3(1) International Journal of Transitional Justice 5; R. Teitel, 'Theoretical and International Frameworks - Transitional Justice in a New Era' (2002) 26 Fordham International Law Journal 893; Arbour (n 10); and Olsen et al (n 11). Editorial (n 7) 1-10.

Olsen et al, (n 11) 11.

Ibid, 11 original footnote 10 .

Editorial (n 7) 6. 
argument that these rights are not 'real' or 'legal' rights or at best constitute secondary rights - general aims to be achieved progressively as the ideal standard. ${ }^{17}$ This view contributes to the argument that economic and social rights are also non-justiciable. ${ }^{18}$ The traditional conception of transitional justice has focussed upon grave violations of civil and political rights as the only justiciable rights that can be tried in a court of law. Therefore, if economic and social rights are not viewed as justiciable rights they cannot be incorporated within this traditional model of transitional justice. This argument is also a consequence of the dependence within the field on a criminal justice model (see below).

Moreover, there remains a general lack of understanding on the part of scholars and practitioners within the field of transitional justice as to what economic and social rights are. For example, scholars have equated such rights with economic policy or development plans rather than comprehending them as distinct and discrete legal entitlements with a legally defined scope and normative content. ${ }^{19}$

\subsection{THE IDEA OF CRIMINAL JUSTICE V OTHER NOTIONS OF JUSTICE}

A third and related argument is that socio-economic rights have been omitted from transitional justice mechanisms because of the focus on criminal justice. ${ }^{20}$ These mechanisms have relied on definitions of justice based in criminal law rather than utilising different conceptions of justice, for example, social justice. This is also due to the dominance of prosecutorial forms of justice. ${ }^{21}$ Arbour has noted, 'As transitional justice is heavily inspired by mainstream justice and criminal law, its neglect of economic, social, and cultural rights is merely symptomatic of a deep ambivalence within justice systems about social justice. ${ }^{22}$ One explanation for this ambivalence towards social justice is the plethora of definitions surrounding the concept. Social justice has been defined as anything from distributive justice to equality of opportunity. ${ }^{23}$ Consequently, the idea of social justice has been largely excluded from the law as either an empty concept with little substance (for example, equality of opportunity) or as a radical concept such as redistributive justice, which can conflict with liberal ideals of human rights and is ideologically and financially unacceptable to many States. However, it is not necessarily undesirable to utilise the concept of social

\footnotetext{
$17 \quad$ Arbour (n 10) 11; D. Sharp, 'Addressing Economic Violence in Times of Transition: Toward a PositivePeace Paradigm for Transitional Justice’ (2012) 35 Fordham International Law Journal 780, 797.

18 R. Carranza, 'Plunder and Pain: Should Transitional Justice Engage with Corruption and Economic Crimes?'(2008) 2 The International Journal of Transitional Justice 310, 315.

For an example of such an approach see Waldorf (n 1).

Waldorf (n 1) 173.

Olsen et al (n 11) 12.

Arbour (n 10) 5 .

Ibid, original footnote 10 .
} 
justice as a basis for expanding our ideas of what transitional justice should include, namely economic and social rights, but that in order to do so we need to define what we mean by social justice. The following definition put forward by Louise Arbour is useful:

Social justice refers to minimum legal standards guaranteeing substantive equality (as reflected in international human rights instruments prohibiting discrimination and protecting economic, social, and cultural rights) in the fulfilment of the idea of freedom from want. Substantive equality is important to social justice, as equality with no qualification may be misinterpreted as formal equality or equality of opportunities only. ${ }^{24}$

This conception of social justice can be defined as 'substantive social justice', where violations of economic and social rights can be seen as an element of social injustice. Therefore, acknowledging and seeking remedy for these violations can be seen as a form of achieving substantive social justice which could be incorporated into transitional justice. Moreover, the link between such rights and social justice is not a new idea. ${ }^{25}$ Indeed, in the context of poverty alleviation, Williams notes that poverty is 'the absence of basic justice for a specific person or groups of persons as a condition of severe material deprivation' where justice is the 'formal, impartial and consistent application of specific rules in relation to rights such as the rights to equality, human dignity, [...] housing, healthcare, food, water, social security, [and] education [...]. The protection and enforcement of these rights would constitute substantive justice'. ${ }^{26}$

It is evident that violations of economic and social rights have been ignored or sidelined within transitional justice as they are not viewed as a legitimate concern for prosecutorial justice or are deemed too difficult an issue for criminal accountability. Rather they can be viewed as an element of social justice which has been excluded from the field. The dependency of transitional justice on criminal justice models has also been critiqued in terms of a general lack of effectiveness. Bell notes, 'the demands of communities do not start and end with the punishment of individuals [...] mechanisms for dealing with the past respond also to demands for truth which cannot be delivered by traditional criminal models. ${ }^{27}$

\footnotetext{
$24 \quad$ Arbour (n 10).

25 See A. Sen, The Idea of Justice (Penguin 2009); J. Rawls, A Theory of Justice (Belknap Press 1971 Reprint 2005); M. Nussbaum, 'Capabilities as Fundamental Entitlements: Sen and Social Justice' (2003) 9(2-3) Feminist Economics 33; and K. Kallen, Social Inequality and Social Injustice - A Human Rights Perspective (Palgrave Macmillan 2004).

26 J. Williams, 'Poverty: A Human Rights Violation in Post-Apartheid South Africa' in T. Pogge (ed), Freedom from Poverty as a Human Right - Theory and Politics (Vol.2) (UNESCO 2010) 321, 345.

27 C. Bell, Peace Agreements and Human Rights (Oxford University Press 2000) 289.
} 


\subsection{ECONOMIC AND SOCIAL RIGHTS AS BACKGROUND INFORMATION}

The overwhelming focus on notions of criminal justice coupled with the argument that socio-economic rights are not legal justiciable rights has resulted in an omission of these rights from the traditional remit of prosecutorial justice. However, how have restorative justice mechanisms such as truth commissions dealt with economic and social rights? It is first important to consider what the purpose of a truth commission is. Olsen states that a truth commission should 'attempt to bring justice by working toward a new inclusive society that addresses the fundamental needs of the population'. ${ }^{28}$ There is a clear development in remit from prosecutorial justice in that a truth commission should attempt to look to the future, not just deal with past abuses in isolation (if this is indeed possible). However, how can the 'fundamental needs of the population' be addressed without addressing economic and social needs (rights) as well as civil and political rights? Attempting to address violations of civil and political rights without addressing related violations of economic and social rights undermines the indivisibility of human rights and does not take into account their interdependence. For example, if someone has been forcibly displaced, their home burnt down and their access to food denied and they subsequently die from starvation and exposure, this would constitute a violation not just of the right to life but also the rights to food, housing and health. Moreover, the failure to address violations of economic and social rights impacts upon the remedy for violations of civil and political rights. For instance, if someone has been subjected to inhumane treatment and is offered rehabilitation as one form of reparation this will be of limited effect if they have no home or no long term sustainable means to support themselves to enjoy an adequate standard of living. Therefore, for a truth commission to fulfil this wider mandate it will need to consider economic and social rights as well as civil and political rights.

Evidence to date suggests that traditionally truth commissions have also limited their consideration of human rights abuses to violations of civil and political rights. ${ }^{29}$ Where truth and reconciliation commissions have considered socio-economic rights they have tended to consider them as evidence of the wider context of the conflict. ${ }^{30}$ Deliberate and direct grave violations have been presented as secondary information, either as supporting evidence of wider conditions of conflict-induced poverty or as background information to explain the context in which civil and political rights' violations have taken place. Exceptionally, a very small number of truth commissions have attempted to address socio-economic rights in a limited manner noting for example that they can be causal factors of conflict. These few cases are examined

\footnotetext{
28 Olsen et al (n 11) 12. See also International Council on Human Rights Policy, 'Aim of a Truth Commission', (n 1) 80.

29 Lisa Laplante, 'On the Indivisibility of Rights: Truth Commissions, Reparations and the Right to Development' (2007) 10 Yale Human Rights and Development Law Journal 141, 142.

30 Sharp (n 17) 793-794.
} 
shortly but an illustrative example can be seen in the case of South Africa, where economic and social problems have been a major consequence of the apartheid system. ${ }^{31}$ During the mandate of the South African Truth and Reconciliation Commission (SATRC) violations of economic and social rights were seen purely as contextual information for narrowly defined gross human rights violations. ${ }^{32}$ Hence, these violations remained in the background of the SATRC rather than being a central concern of the body.

\subsection{THE NATURE AND SCOPE OF ECONOMIC AND SOCIAL RIGHTS VIOLATIONS}

The idea of economic and social rights as contextual information can be seen as closely linked to the problematic issue of dealing with transition in countries which prior to the conflict had pre-existing violations of economic and social rights or, at the very least economic and social conditions which threatened the enjoyment of such rights by sectors of society (due to discrimination and inequality). Whilst in some cases it will be easy to identify specific acts of violence against individuals and communities that constitute grave violations of economic and social rights, in other cases these violations will be a result of structural and endemic violence and repression by the State, for example the former apartheid system in South Africa.

This raises the question of whether transitional justice should include consideration of historical injustices within a State or consider only limited episodes of violence. ${ }^{33}$ If the latter is true this may have an impact on economic and social rights violations that are a result of structural violence and structural injustices that pre-date the conflict or which may have helped instigate it. ${ }^{34}$ Structural violence exists when the structures of the State support the unequal distribution of power (and agency) which is reinforced through unequal distribution of resources. ${ }^{35}$ Thus structural violence based upon this 'unequal distribution of power then systematically disadvantages those who do not hold as much if any power at all'. ${ }^{36}$ Examples of such structural violence can include racial inequality, poverty and institutionalised discrimination. Moreover, the link between structural violence and violations of economic and social rights is clear. Ho notes that 'When economic and social structures conspire to limit one's agency to

\footnotetext{
$31 \quad$ Ibid.

32 South African Truth and Reconciliation Commission, Truth and Reconciliation Commission of South Africa Report Vol. 5, Chapter 1 Analysis of Gross Violations of Human Rights (South African Truth and Reconciliation Commission 1998) 11, para 48.

33 Editorial (n 7) 3.

$34 \quad$ Sharp (n 17) 802.

35 For a definition and discussion of the meaning of structural and or institutional and indirect violence see J. Galtung, 'Violence, Peace, and Peace Research' (1969) 6(3) Journal of Peace Research 167, 170. See also P. Farmer, Pathologies of Power (University of California Press 2005).

36 K. Ho, 'Structural Violence as a Human Rights Violation' (2007) 4(2) Essex Human Rights Review 1, 4.
} 
the extent that fundamental human needs cannot be met then structural violence becomes a structural violation of human rights. ${ }^{37}$

Thus, the perceived difficulty with outlining the scope and nature of socioeconomic rights violations to be considered by transitional justice bodies is a further reason why such violations have been sidelined within the discipline. Nevertheless, these structural socio-economic violations can cause both frustration and unrest which in turn can drive conflict. If there is no attempt to address these structural and societal inequalities then the risk is that conflict will resurface despite efforts to address more direct violations of economic and social rights within transitional justice mechanisms. As such, there is a question to be answered as to how these mechanisms can address not only grave violations of such rights that have taken place as a deliberate and direct result of the conflict, but also systematic and structural violations of economic and social rights that act as an ongoing source of injustice and root cause of the conflict itself. Laplante notes, 'presenting socioeconomic root causes of conflict as historical context leaves policy change to the discretion of political leaders, while presenting them as rights violations makes redress and reform a political imperative'. ${ }^{38}$

\section{WIDER AND DEEPER TRANSITIONAL JUSTICE}

As previously stated, in the past, dominant thinking and practice in transitional justice has focussed on addressing civil and political rights violations that have occurred during the conflict and measures to deal with the past. This can be deemed 'traditional' transitional justice. However, the International Centre for Transitional Justice ${ }^{39}$ provides a more progressive definition of transitional justice: 'Transitional justice is a response to systematic or widespread violations of human rights. It seeks recognition for the victims and to promote possibilities for peace, reconciliation and democracy [...]'.40 The focus remains on 'systematic and widespread' violations of human rights, but the nature of violations is not defined. As such, in theory it does not exclude violations of economic and social rights. Furthermore, the definition clearly characterises transitional justice as responsive to past events (as in the previous definition) but also as having a positive role in the future with the phrase: 'promote possibilities for peace, reconciliation and democracy [...]'. One could argue that clearly transitional justice must include responding to grave violations of economic and social rights (as well as civil and political rights violations) that have occurred in the past but also that promoting possibilities for peace needs to include measures

Ibid 15.

Laplante (n 1) 341.

Hereinafter referred to as ICTJ.

International Centre for Transitional Justice (n 12). 
to prevent further violations of economic and social rights, including addressing underlying inequality, discrimination and poverty.

Boraine has called for a 'holistic interpretation' of transitional justice ${ }^{41}$ while not detracting from criminal justice, this approach 'offers a deeper, richer and broader vision of justice'. ${ }^{2}$ McEvoy and McGregor also argue for 'thicker transitional justice' - a move away from strict legalism to include other aspects of justice necessary for transition to peace. ${ }^{43}$ Consequently, a broader and more holistic definition of transitional justice can be envisaged, which would include traditional mechanisms with a mandate to investigate and seek remedy for grave violations of both economic and social rights and civil and political rights. This would bring economic and social rights firmly to the foreground of traditional mechanisms and would constitute the first step in the development of a wider and deeper remit for transitional justice.

Furthermore, wider and deeper transitional justice should be considered an integral element of peacebuilding. Such transitional justice might encompass measures (some of which may have previously been seen as a concern for peacebuilding) that are less legalistic and look to the future as well as deal with the past. These could include, for example, recommendations for legal reforms and protections such as bills of rights and other constitutional guarantees, ${ }^{44}$ as well as a rights-based approach to development, ${ }^{45}$ institutional reform ${ }^{46}$ and institution building, including the establishment of new institutions to monitor economic and social rights such as a national human rights institution. ${ }^{47}$ Such an approach to transitional justice has been seen as 'shifting the paradigm' from one of transition to one of transformation (transformative justice). ${ }^{48}$

Conversely, this wider and deeper approach to transitional justice has been challenged. Waldorf notes that whilst transitional justice is struggling to deliver on its 'original promises of truth, justice and reconciliation' more demands are being

\footnotetext{
$41 \quad$ Boraine (n 8).

42 Ibid 18.

43 K. McEvoy and L. McGregor, (eds), Transitional Justice From Below: Grassroots Activism and the Struggle for Change (Hart 2008).

44 OHCHR (n 1) para.63.

45 McEvoy and McGregor (n 44) 33-37; See also P. De Greiff and R. Duthie (eds), Transitional Justice and Development - Making Connections (Social Science Research Council 2009); R. Mani, 'Editorial - Dilemmas of Expanding Transitional Justice, or Forging the Nexus between Transitional Justice and Development' (2008) 2 The International Journal of Transitional Justice 253.

46 C. Sandoval Villalba, Transitional Justice: Key Concepts, Processes and Challenges, Institute for Democracy and Conflict Resolution Briefing Paper (IDCR-BP-07/11) (IDCR/University of Essex 2011). See also Office of the High Commissioner for Human Rights, Rule of Law Tools for PostConflict States: Truth Commissions, (United Nations 2006).

47 See A. Cahill-Ripley, From Peace Agreements to Post-Conflict Reconstruction: Economic and Social Rights and Peacebuilding (forthcoming article, on file with author).

48 See Sharp (n 17) 804. See also M. Evans, 'Land, socio-economic rights and transformative justice', Paper presented at Land Divided: Land and South African Society in 2013, in Comparative Perspective conference (University of Cape Town, 24-27 March 2013).
} 
placed on it. ${ }^{49}$ Moreover, Mani states that it is difficult to see how remedy for such broadly encountered social injustice could be incorporated into 'targeted' transitional justice measures. ${ }^{50}$ Waldorf argues that despite increasing calls for a broadening of the remit for transitional justice, it should be 'short-term, legalistic and corrective' and, as such, should focus on gross violations of civil and political rights alone. ${ }^{51}$ Practical difficulties, he notes, include inflating public expectations of transitional justice mechanisms, the existing limited financial capacity of mechanisms and the long-term nature of dealing with economic and social rights violations. However, it is argued that the limited financial capacity of any transitional justice mechanism is relevant to investigation and remedy of any human rights violations whether civil and political rights or economic and social rights. For example, it may take many years for a functioning tribunal to bring war criminals to justice whether they have committed grave violations of civil and political rights or economic and social rights. In terms of financial costs of reparations programmes, a reparations programme for individual victims of torture may cost just as much as communal reparations to provide adequate housing. The decision as to how best to limit the capacity and funding of a transitional justice mechanism should be based upon the nature and scope of the violations encountered as well as 'a careful analysis of the drivers of conflict', not on an arbitrary distinction between civil and political rights violations and socio-economic rights violations. ${ }^{52}$ Questions of time, money and expertise are relevant for all human rights considerations. Further, as Schmid notes, the challenges of competing demands, resource constraints and high expectations are not unique to the inclusion of economic and social rights within transitional justice but are challenges encountered more widely in the entire process of peacebuilding within post-conflict reconstruction of a State. ${ }^{53}$

Waldorf argues that the remedy for violations of economic and social rights should be a matter for 'democratic politics and distributive justice'. ${ }^{54}$ However, this view of economic and social rights perceives them not as legal entitlements but as social aims or policy goals and supports the view previously presented that such rights have been ignored precisely because they are not conceived of as legal rights. This illustrates a fundamental misunderstanding of what economic and social rights are. Economic and social rights cannot be equated with development or broad economic policies. They are discrete and justicable legal entitlements with a legally defined scope, normative content and correlative obligations. ${ }^{55}$

\section{Waldorf (n 1) 172.}

R. Mani (n 45) 255.

Waldorf (n 1) 179.

Sharp (n 17) 805.

Schmid (n 5) 17-18.

Waldorf (n 1) 179; Schmid (n 5) 17-18.

There are many sources which provide for economic, social and cultural rights within international human rights law, constitutional provisions and national legislation. However, the main 
Moreover, Waldorf ignores the fact that violations of such rights are often a result of deliberate violent acts carried out during conflict seeming to suggest instead that socio-economic rights violations are solely due to poverty and/or inequality. This is clearly not the case. Many direct and deliberate violations of economic and social rights take place within conflict as noted previously. Furthermore, even if certain violations of economic and social rights are a result of inequality and discrimination, this is likely to have been exacerbated by the conflict and needs to be addressed. Both structural violations of economic and social rights and direct violations of economic and social rights are human rights violations - they are not simply 'under development' as suggested. Moreover, he argues that the 'reduction of longstanding inequality is necessarily post-transitional'56 but it is not clear when the transitional period ends and the post-transitional period begins. If, as Waldorf seems to suggest, inequality is left unchecked whilst in transition, it is difficult to see how this would contribute to the goal of justice. Without tackling inequality there can only be partial or limited justice and the seeds of future conflict remain. As Sharp argues, transitional justice cannot be just and meaningful if a 'significant portion of the drivers of conflict and resulting violations of international law are pushed to the side'. ${ }^{57}$ Waldorf argues that to include economic and social rights within the remit of transitional justice is casting the net too wide. ${ }^{58}$ However, the argument that diversifying the remit of transitional justice results in a weakening of these mechanisms is not borne out in practice. In fact, the opposite may be true. Carranza argues that the efficacy of these mechanisms is actually enhanced by the inclusion of economic and social rights as the process is more holistic and with less room for gaps in addressing the needs of the population. ${ }^{59}$

Another challenge to the inclusion of economic and social rights within transitional processes is the implicit assumption that if we include these rights then we 'dilute' the seriousness of grave violations of civil and political rights, that is, by recognising violations of economic and social rights it would somehow diminish the gravity of mass violations and severe crimes such as genocide. This assumption may be based on the historical view of economic and social rights as secondary rights of a lesser importance or not real rights, as mentioned previously. It is not suggested, for example, that lack of housing due to conflict can be equated with genocide. However, starving people to death through deliberate blocking of food aid as seen in Zimbabwe, ${ }^{60}$ or forced displacement as experienced in Timor-Leste, ${ }^{61}$ can be as

international instrument is the UN International Covenant on Economic, Social and Cultural Rights (adopted 16 Dec 1966, entered into force 3 Jan 1976) 993 UNTS 14531 (ICESCR).

56 Waldorf (n 1) 179.

$57 \quad$ Sharp (n 17) 805.

$58 \quad$ Waldorf (n 1) 179.

59 Carranza (n 18) 322.

60 Rhoda Howard-Hassmann, 'Mugabe's Zimbabwe, 2000-2009: Massive Human Rights Violations and the Failure to Protect' (2010) 32(4) Human Rights Quarterly 898.

61 The Commission for Reception, Truth and Reconciliation in Timor-Leste, Forced Displacement and Famine, National Public Hearing, 28-29 July 2003 (CAVR 2005). 
severe as crimes against humanity or war crimes of direct violence. Moreover, they may constitute such crimes in and of themselves. ${ }^{62}$ It is evident therefore that in the first instance transitional justice mechanisms need to recognise that gross violations of human rights include severe and systematic violations of economic and social rights $^{63}$ and that such bodies establish a mandate for dealing with such violations. In addition, transitional justice mechanisms also need to recognise that some economic and social rights violations may be the result of more structural violence endemic in the State and/or region.

\section{EXPERIENCES TO DATE - WHAT CAN WE LEARN FROM PAST PRACTICE?}

Within academia researchers have begun to explore a broader mandate for transitional justice; ${ }^{64}$ some authors have considered the role of 'economic crimes', ${ }^{65}$ others the link between transitional justice and development. ${ }^{66}$ In practice, however, States in transition from conflict or repression continue to choose criminal prosecutions and truth commissions as the primary methods for seeking justice for human rights abuses. ${ }^{67}$ Therefore, the first step to foregrounding economic and social rights within transitional justice is for these violations to be considered as genuine breaches of the relevant law ${ }^{68}$ and as legitimate concerns for traditional mechanisms, both prosecutorial and restorative. It is therefore important to examine the past practice of both prosecutorial justice mechanisms and restorative justice mechanisms to assess how they have dealt with economic and social rights violations and to draw upon any examples of good practice for future integration of such rights within these processes.

62 See L. van den Herik, 'Economic, Social and Cultural Rights - International Criminal Law's Blind Spot' (2013) Grotius Centre Working Paper 2013/002-ICL (University of Leiden 2013).

63 Office of the High Commissioner for Human Rights, Commission On Human Rights, Study concerning the right to restitution, compensation and rehabilitation for victims of gross violations of human rights and fundamental freedoms, Final report submitted by Mr. Theo van Boven, Special Rapporteur (2 July 1993) E/CN.4/Sub.2/1993/8 para 12 notes that gross violations of human rights 'frequently effect' economic, social and cultural rights.

64 I. Muvingi, 'Sitting on Powder Kegs: Socioeconomic Rights in Transitional Societies' (2009) 3 International Journal of Transitional Justice 163; Waldorf (n 1); Arbour (n 10).

65 Z. Miller, 'Effects of Indivisibility: In Search of the "Economic" in Transitional Justice' (2008) 2 International Journal Transitional Justice 266; Carranza (n 18).

66 For example see De Greiff and Duthie (n 45); Mani (n 45); and Laplante (n 29) 141-177.

67 See Editorial (n 7) 1.

68 Whether deemed a crime or a human rights violation under International human rights law, international criminal law, international humanitarian law, refugee law and relevant domestic provisions. 


\subsection{PROSECUTORIAL FORMS OF JUSTICE AND ECONOMIC AND SOCIAL RIGHTS}

The focus of prosecutorial forms of transitional justice within international law has been on mechanisms based upon the framework of international criminal law. ${ }^{69}$ These measures usually take the form of an international court such as the International Criminal Court (ICC) or a tribunal set up for a specific State / conflict such as the International Criminal Tribunal for the Former Yugoslavia (ICTY). Although the legal basis for such courts and tribunals includes provisions which can be applied to violations of economic and social rights it is evident that in the majority of these processes there has been little or no consideration of such rights violations as a part of wider gross human rights violations or as crimes in their own right. When considering the law there are clearly international criminal law provisions which could apply to such gross violations of socio-economic rights, ${ }^{70}$ but very little attention has been given to exploring the potential or limitations of this area of the law to deal with such violations. ${ }^{71}$

The Office of the High Commissioner for Human Rights' Analytical study on human rights and transitional justice states that 'International criminal tribunals have investigated and prosecuted cases of violations of economic, social and cultural rights, stating that, the ICTY has recognized that the widespread destruction of homes and property may constitute a crime against humanity'. ${ }^{72}$ Furthermore, they note the case of Prosecutor v. Kupreskic et al. ${ }^{73}$ where the Trial Chamber found that

[...] attacks on property can constitute persecution. [...] comprehensive destruction of homes and property. Such an attack on property in fact constitutes a destruction of the livelihood of a certain population. This may have the same inhumane consequences as a forced transfer or deportation. Moreover, the burning of a residential property may often be committed with recklessness towards the lives of its inhabitants. The Trial Chamber therefore concludes that this act may constitute a gross or blatant denial of fundamental human rights, and, if committed on discriminatory grounds, it may constitute persecution. ${ }^{74}$

69 In this instance I do not discuss other mechanisms such as national courts established for transitional justice purposes.

70 For example, under the International Criminal Court Rome Statute, Art 8 (2) (b) (xxv) starvation as a weapon of war is a specific crime, however to date no one has been indicted on this charge. Other possible provisions include ICC Rome Statute, Article 7 (1) (b) Crime against humanity of extermination; Article 7 (1) (h) Crime against humanity of persecution, Article 8 (2) (a) (iii) War crime of wilfully causing great suffering; Article 8 (2) (a) (iv) War crime of destruction and appropriation of property; Article 8 (2) (b) (ii) War crime of attacking civilian objects; ICC Rome Statute, Article 6(c) by deliberately inflicting conditions of life calculated to bring about physical destruction.

71 Van den Herik (n 62).

72 Office of the High Commissioner for Human Rights (n 2) para.61.

73 Prosecutor v Kupreskic et al (Judgment) ICTY, IT-95-16-T (14 January 2000) paras 628-631.

74 Ibid para. 631. See also Prosecutor v Stanislav Galić (Judgment) ICTY, IT-98-29-T (5 December 2003) para.42 and Prosecutor v Blaskić (Judgment) ICTY, IT-95-14-T (3 March 2000) where damage 
However, despite this acknowledgement that economic and social rights violations can constitute crimes under international criminal law, these violations are not explicitly recognised as violations of economic and social rights. Rather, 'the broad crime definitions of persecution and crimes against humanity offer some leeway to "import" socio-economic human rights notions'75 into a criminal law framework. Although this illustrates a positive development in that such violations are explicitly addressed as possible of constituting gross violations of human rights under international criminal law, it remains disappointing that the explicit identification of such crimes as economic and social rights violations remains an omission. As van den Herik notes 'there is no direct criminalisation of socio-economic rights, but rather a pronounced appreciation of the socio-economic dimensions of crimes. ${ }^{76}$

It is also the case that in other trials at the ICTY, despite evidence of severe economic and social rights violations, these acts were relegated to the role of background contextual information for civil and political rights violations as constitutive of international crimes. For example, in Prosecutor v. Dragomir Milošević,77 the Trial Chamber held that the siege of Sarajevo was 'characterised by a persistent attack or campaign over a period of fourteen months, during which the civilian population was denied regular access to food, water, medicine and other essential supplies, and deprived of its right to leave the city freely at its own will and pace. ${ }^{78}$ However, the trial did not note any violations of economic and social rights as an element of either crimes against humanity or unlawful attacks against civilians. More generally, the deliberate starvation of civilians and burning and destruction of homes was widely documented as evidence to form a picture of the wider context in which violations of personal integrity rights took place. These violations of economic and social rights have not been acknowledged as such nor has anyone been indicted for these violations as constituting an element of a crime against humanity or a war crime. ${ }^{79}$

Likewise, the ICC has not explicitly referred to economic and social rights violations as elements of relevant crimes despite evidence and indictments noting what amounts to severe violations of such rights. For example, in the first warrant

to civilian property was seen as an element of an attack on Civilians as a Violation of the Laws or Customs of War as set forth in Article 51 of Additional Protocol I and Article 13 of Additional Protocol II to the Geneva Conventions of 1949) punishable under Article 3 of the Statute of the Tribunal.

$75 \quad$ Van den Herik (n 62) 8.

76 Ibid.

77 Prosecutor v Dragomir Milošević (Judgment) International Criminal Tribunal for the Former Yugoslavia (ICTY) IT-98-29/1-T (12 December 2007).

$78 \quad$ Ibid para 751.

79 There is no specific provision under ICTY for a crime of starvation as weapon of war as there is in the Rome Statute of the International Criminal Court 1998 Art 8 ICC Art 8 (2)(b)xxv. However the definition of crimes against humanity could encompass deliberate starvation. 
of arrest in Prosecutor v. Omar Hassan Ahmad Al Bashir (Omar Al Bashir), ${ }^{80}$ the Prosecution submits that

GoS (Government of Sudan) forces systematically destroyed the means of survival including food, shelter, crops, livestock and, in particular, wells and water pumps - of the Fur, Masalit and Zaghawa civilian population in Darfur because "[t]he aim was to ensure that those inhabitants not killed outright would be unable to survive without assistance". ${ }^{81}$ In this regard, the Prosecution submits that: Given Darfur's hostile desert environment and lack of infrastructure, livelihood strategies historically have centred on the village. It is difficult to survive outside the communal setting. As an example, ensuring adequate access to water has long been an essential component of livelihood strategies. To facilitate access to water by both humans and animals, many villagers dug communal wells or maintained other communal water sources. Militia/Janjaweed and the Armed Forces repeatedly destroyed, polluted or poisoned these wells so as to deprive the villagers of water needed for survival. In a number of cases, water installations were bombed. ${ }^{82}$

This can clearly be viewed as a severe violation of the rights to food, water and housing as well as constituting elements of crimes against humanity, ${ }^{83}$ and war crimes. ${ }^{84}$ Skogly argues that crimes against humanity should include severe violations of economic and social rights. ${ }^{85}$ Further examples of such economic and social rights violations include deliberate blockage of food aid ${ }^{86}$ as seen in the

80 Prosecutorv Omar Hassan Ahmad Al Bashir (“Omar Al Bashir") (International Criminal Court PreTrial Chamber I, Decision on the Prosecution's Application for a Warrant of Arrest against Omar Hassan Ahmad Al Bashir) ICC-02/05-01/09 (4 March 2009).

81 The Prosecution Application, para 175(Footnote in original document).

82 Prosecutorv Omar Hassan Ahmad Al Bashir ("Omar Al Bashir") (International Criminal Court PreTrial Chamber I, Decision on the Prosecution's Application for a Warrant of Arrest against Omar Hassan Ahmad Al Bashir) ICC-02/05-01/09 (4 March 2009) para 91. Original footnote omitted. See also para 93. However, it was also noted that 'there are no reasonable grounds to believe that such a contamination was a core feature of their attacks,' 32 .

83 In particular, Rome Statute of the ICC, The Elements of Crimes, (reproduced from the Official Records of the Assembly of States Parties to the Rome Statute of the International Criminal Court, First session, New York, 3-10 September 2002, 6, Article 7(1)(b) Crime against humanity of extermination; Elements ' 1 . The perpetrator killed one or more persons, including by inflicting conditions of life calculated to bring about the destruction of part of a population,' directly or indirectly and including through depriving access to food and medicines and Article 7(1)(h) Crime against humanity of persecution, Elements, '1. The perpetrator severely deprived, contrary to international law, one or more persons of fundamental rights.'

84 Specifically Rome Statute of the ICC Article 8(2)(a)(iii) War crime of wilfully causing great suffering; Article 8(2)(a)(iv) War crime of destruction and appropriation of property (ICC Elements of Crimes page 15); Article 8(2)(b)(ii) War crime of attacking civilian objects (ICC Elements of Crimes, page 18) and Article 8(2)(b)(xxv) War crime of starvation as a method of warfare (ICC Elements of Crimes, page 31).

85 S.I. Skogly, 'Crimes Against Humanity - Revisited: Is There a Role for Economic and Social Rights?' (2001) 5(1) The International Journal of Human Rights 58, 59.

86 Ibid 69-70. 
Sudan ${ }^{87}$ or deliberate State-induced famine as seen in Zimbabwe. ${ }^{88}$ The President of Zimbabwe, Robert Mugabe, deliberately denied international agencies permission to bring food into Zimbabwe to feed the starving. Despite unprecedented food shortages he distributed State-owned grain to his supporters whilst withholding it from opposition supporters. ${ }^{89}$ Thus, in the period from 2000 to 2009, the policies of the Zimbabwean government can be considered as State-induced famine and as such constitute a crime against humanity under international criminal law. ${ }^{90}$ Their actions can also be viewed as deliberate violations of the right to food, health and housing. Yet, Mugabe has never been indicted for these crimes at the ICC, despite calls for his indictment. ${ }^{91}$

It is also the case that gross violations of economic and social rights can constitute genocide. ${ }^{92}$ For example, in the second warrant of arrest Prosecutor $v$ Omar Hassan Ahmad Al Bashir, Bashir has been indicted on the count of genocide by deliberately inflicting conditions of life calculated to bring about physical destruction, within the meaning of article 6(c) of the Statute. This includes

[...] reasonable grounds to believe that in furtherance of the genocidal policy, as part of the GoS's unlawful attack on the above-mentioned part of the civilian population of Darfur and with knowledge of such attack, GoS forces throughout the Darfur region (i) at times, contaminated the wells and water pumps of the towns and villages primarily inhabited by members of the Fur, Masalit and Zaghawa groups that they attacked. ${ }^{93}$

Clearly these acts amount to a violation of the right to water as well as the right to life.

These examples illustrate the marginalisation of economic and social rights violations within prosecutorial transitional justice mechanisms and more broadly within international criminal law. Van den Herik argues that international criminal law has the potential to capture such large-scale and deliberate socio-economic rights violations but that the 'rigid legal requirements' of criminal law results in a marginal role for international criminal processes in addressing such violations. For example, the focus upon commission of acts rather than omission and the strict definition of

\footnotetext{
$87 \quad$ A. de Waal, Famine Crimes: Politics and the Disaster Relief Industry in Africa (The International African Institute, in association with James Currey, Oxford and Indiana University Press 1997). Howard-Hassmann (n 60). Ibid 901; 908 .

93 Prosecutor v Omar Hassan Ahmad Al Bashir ("Omar Al Bashir") (Second Warrant of Arrest against Omar Hassan Ahmad Al Bashir) ICC-02/05-01/09 (12 July 2010) 7. See also footnote in original, Physicians for Human Rights, Report, Darfur Assault on Survival, A call for Security, Justice, and Restitution (Anx J44) DAR-OTP-0119-0635 at 0679 which mentions three incidents of destruction of water sources).
} 
crimes and legality principle of the $\mathrm{ICC}^{94}$ leave 'less space for direct recourse to human rights in the realm of substantive criminal law'. ${ }^{95}$ However, despite these difficulties there are, as illustrated, provisions that can accommodate such violations. It is clear that systematic and large scale abuse of such rights can meet the threshold required to constitute a crime against humanity, war crimes or even genocide. Furthermore, to limit such crimes to violations of civil and political rights is an arbitrary limitation that should be challenged'. ${ }^{96}$ Violations of economic and social rights that are of a severe nature and can be considered under the relevant international criminal law should be the subject of established prosecutorial mechanisms such as international courts and tribunals, just as gross violations of civil and political rights are. Such international courts and tribunals clearly have the capacity to consider economic and social rights violations within existing international criminal law and international humanitarian law, helping to increase the visibility of socio-economic abuses. ${ }^{97}$ As Schmid argues, there are no legal obstacles in doing so. ${ }^{98}$

\subsection{RESTORATIVE JUSTICE AND ECONOMIC AND SOCIAL RIGHTS (TRUTH AND RECONCILIATION COMMISSIONS)}

If violations of economic and social rights do not reach the threshold required by international criminal law to be considered under the above noted provisions there is a need for mechanisms to address violations of a less severe nature. A truth commission, for example, can incorporate within their mandate international human rights standards that do not necessarily require such a high threshold to be reached before violations can be considered. With this in mind it may be that restorative justice mechanisms are more appropriate in certain cases for dealing with economic and social rights violations as they can encompass severe and systematic violations of economic and social rights but also those of a lesser gravity. ${ }^{99}$ Further, they are not subject to the same strict legal modalities of international criminal law. In terms of assessing and examining previous practice, however, there are few examples of truth commissions who have fully engaged with economic and social rights. As stated above, exceptionally a small number have addressed such rights in a limited and incomplete manner. Accordingly, this paper will focus upon the limited cases where the commission have engaged in some way with economic and social rights or have encountered such rights violations as a significant element of the conflict.

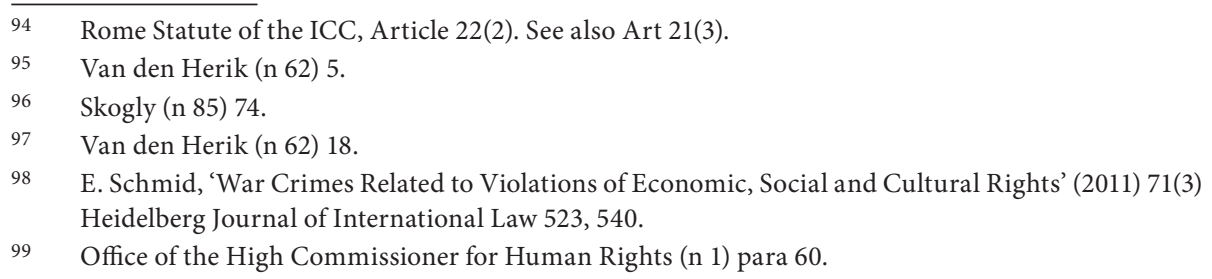




\title{
4.2.1. South Africa
}

The South African Truth and Reconciliation Commission is probably the most wellknown and researched truth and reconciliation commission in the world. However, very little attention has been given to analysing how it dealt with economic and social rights within the transitional justice process. The Commission was limited in its mandate by the definition of gross human rights violations provided for in the founding legislation which stated,

\begin{abstract}
"gross violation of human rights" means the violation of human rights through - (a) the killing, abduction, torture or severe ill treatment of any person; or (b) any attempt, conspiracy, incitement, instigation, command or procurement to commit an act referred to in paragraph (a), which emanated from conflicts of the past and which was committed during the period 1 March 1960 to 10 May 1994 within or outside the Republic, and the commission of which was advised, planned, directed, commanded or ordered, by any person acting with a political motive. ${ }^{100}$
\end{abstract}

This definition limited the attention of the Commission to events which emanated from the conflicts of the past, rather than from the policies of apartheid. ${ }^{101}$ Whilst it is understandable that the Commission felt it could not undertake responsibility for investigating the entire and extensive affects of apartheid, this does not mean that deliberate and gross violations of socio-economic rights could not have been deemed 'severe ill treatment' under the existing mandate. Furthermore, the narrow definition of human rights violations was not in line with public expectations of the Commission, which was asked to investigate forced evictions and displacement and discrimination in education, work and other economic and social rights violations, especially those faced by women. The Commission did hold 'Institutional and Special Hearings' relating to inter alia business, the healthcare system and women. ${ }^{102}$ These hearings noted the structural violence and associated violations as a result of the apartheid system. However, it is disappointing that in its final report the Commission noted that 'these issues formed part of the broader context within which the specifically defined gross human rights violations had taken place. ${ }^{103}$ Thus, economic and social rights violations were positioned firmly in the background, as contextual information.

100 (South Africa) Promotion Of National Unity And Reconciliation Act 34 of 1995, section 1(1)(ix) [definition of 'gross violation of human rights' amended by s. 21 (a) of act 104 of 1996]. See also South African Truth and Reconciliation Commission, Truth and Reconciliation Commission of South Africa Report 1998, Vol.1 Chapter 4, Defining Gross Violations Of Human Rights (South African Truth and Reconciliation Commission 1998) 70-78, paras 82-90.

101 South African Truth and Reconciliation Commission (n 32) para 48.

102 South African Truth and Reconciliation Commission, Truth and Reconciliation Commission of South Africa Report 1998, Vol. 4 Institutional and Special Hearings (South African Truth and Reconciliation Commission 1998).

103 South African Truth and Reconciliation Commission (n 32) paras 48 and 49. 
Individuals who were a subject of these violations were excluded from recognition as victims and from reparations. ${ }^{104}$

\subsubsection{Liberia}

The Republic of Liberia Truth and Reconciliation Commission had a broad mandate to address all gross violations of human rights, including an explicit reference to economic and social rights but this was qualified by a statement linking these violations to 'economic crimes'. ${ }^{105}$ Although the Commission recognised that such violations were a major root cause of the conflict, noting that poverty, corruption, limited access to education, economic, social, civil and political inequalities and land tenure and distribution, were all contributing factors, ${ }^{106}$ the Commission failed to translate this recognition of economic and social rights violations into a primary concern for the truth and reconciliation commission. As Schmid notes there is a significant gap between the findings of the Commission in relation to the causes of conflict and the legal analysis of abuses committed. ${ }^{107}$ The focus instead was on economic crimes - that is on crimes related to corruption that had economic impacts rather than on a rightsbased analysis of violations. This raises the issue of the differences between economic and social rights violations and the concept of economic crimes. In some cases they have been treated as synonymous with one another, however, it is argued that this is not the case. Sharp refers to the concept of 'economic violence' but acknowledges that this is a broader concept than purely violations of economic and social rights also including corruption and plunder of natural resources within the definition. ${ }^{108}$ Although the latter have also been sidelined within transitional justice it is important to differentiate between economic and social rights violations under international law and the wider crimes which can lead to such violations. ${ }^{109}$

\subsubsection{Sierra Leone}

Similarly, the Sierra Leone Truth and Reconciliation Commission had a mandate to consider 'Violations of economic, social and cultural rights as well as of civil and

\footnotetext{
$104 \quad$ Ibid.

105 Republic Of Liberia Truth and Reconciliation Commission, Final Report Volume One Preliminary Findings and Determinations (The Truth and Reconciliation Commission of Liberia 2008) Section ii, 23.

106 Ibid 4, note.2. For the Commission's definition of economic crimes and further discussion see Republic Of Liberia Truth and Reconciliation Commission Final Report Volume Three: Appendices, Title III: Economic Crimes and the Conflict, Exploitation and Abuse (The Truth and Reconciliation Commission of Liberia 2009) 2, para 8.

107 Schmid (n 5) 6.

108 Sharp (n 17) 782.

109 Ibid 785. Further research is required on the relationship between economic crimes such as corruption and ESR. Notable publications include Carranza (n 18); and Schmid (n 5) 19.
} 
political rights, as well as other categories of rights such as the right to development and the right to peace'. 110 The report acknowledges that,

In any event, human rights violations and abuses will often have both civil or political, and economic, social and cultural dimensions. [...] Indeed, although wartime atrocities usually involve the "core" human rights, like the right to life and the protection against cruel and inhuman treatment, the conflict in Sierra Leone may also have involved, and have been caused by, "violations of such economic and social rights as the right to food, to housing and to medical care".111

In the resulting investigation, the Commission did investigate and report on aspects of economic and social rights such as education and health especially in relation to children ${ }^{112}$ and women. In a move to be commended it held a special hearing for women and girls. The Commission found that women bore the brunt of economic and social rights violations such as destruction of property, forced evictions and displacement, ${ }^{113}$ but the legal analysis never explicitly framed these abuses as human rights violations (right to housing, food and water for example). In terms of reparations, the programme was necessarily limited due to resources. The priority entitlement was defined not by the type of violations suffered but by identifying the most vulnerable. ${ }^{114}$ As such, the Commission prioritised reparations for widows, children and in the areas of health, education, pensions and community reparations. ${ }^{115}$ Despite the fact that the reparations programme did address some issues which remedied economic and social rights violations ${ }^{116}$ these reparations were not recognised as remedies for violations of such rights and therefore were not framed as legal entitlements. Rather, these issues were addressed because they were deemed important policy issues and priorities for the identified vulnerable groups.

In sum, the above cases of Liberia and Sierra Leone illustrate that even if economic and social rights are explicitly provided for in the mandate and acknowledged as a causal factor of the conflict, it does not necessarily follow that truth and reconciliation

110 Sierra Leone Truth and Reconciliation Commission, Witness to Truth - Report of the Sierra Leone Truth and Reconciliation Commission Vol. 1 (Sierra Leone Truth And Reconciliation Commission 2004) 38, para 54.

$111 \quad$ Ibid para 52.

112 See Sierra Leone Truth and Reconciliation Commission Witness to Truth - Report of the Sierra Leone Truth and Reconciliation Commission Vol. 2, Chapter 2 Findings (Sierra Leone Truth And Reconciliation Commission 2004) para 489; para 490.

113 Sierra Leone Truth and Reconciliation Commission, Witness to Truth - Report of the Sierra Leone Truth and Reconciliation Commission Vol.3B, Chapter Three Women and the Armed Conflict in Sierra Leone (Sierra Leone Truth And Reconciliation Commission 2004) 185, para 386; See also Vol.2, Chapter 2 Findings: Women, para 497; para 499.

114 Sierra Leone Truth and Reconciliation Commission (n 112) para 57.

115 Ibid paras 84 and 85.

116 Such as lack of access to land; training and education; See Sierra Leone Truth and Reconciliation Commission (n 112) para 499; (n 113) 185 para 499. 
commissions will apply a rights based framework to such violations or highlight them as a priority for the said commission.

\subsubsection{Timor - Leste (East Timor)}

In the case of The Commission for Reception, Truth and Reconciliation in TimorLeste, (CAVR) the commission also acknowledged and investigated violations of economic and social rights violations. The Commission's mandate stated that they would enquire into 'Violations of a broad range of human rights standards' including rights and freedoms within, inter alia, the UN International Covenant on Economic, Social and Cultural Rights $1966 .{ }^{117}$ The CAVR was also important in that it highlighted and recognised within its mandate the interdependence of rights. ${ }^{118}$ For example, a disappearance constitutes a violation not only of personal integrity rights (civil and political rights) but also where a family was economically dependent on the disappeared person may violate economic and social rights such as the right to an adequate standard of living. ${ }^{119}$

The Commission chose to focus on an examination of the most serious violations of fundamental rights and focused in particular on inter alia, 'The range of rights relevant to displacement, resettlement and famine (the right to food, freedom from hunger, water and adequate housing, freedom of movement, freedom to choose a residence)'120 and 'Social and economic rights'. ${ }^{121}$ The result was an in-depth report detailing extensive violations in relation to the rights to food, water, health, housing and education. ${ }^{122}$ The deliberate policy of forced displacement led to famine, 'hunger and deprivation of the means of making a livelihood through the destruction of or

117 The Commission for Reception, Truth and Reconciliation in Timor-Leste, Chega! The Report of the Commission for Reception, Truth and Reconciliation in Timor-Leste (CAVR) (Commission for Reception, Truth and Reconciliation 31 October 2005) Part 2 - The Mandate of the Commission, 4 , para 15. Other sources used include international human rights law but also international criminal law (such as crimes against humanity Art 7(2)(b) Rome Statute on extermination through deprivation of food) and international humanitarian law (for example, starvation as a weapon of war under grave breaches of the laws of war), as well as national law (for example, poisoning of water sources under Indonesian law).

118 As did the Sierra Leone Truth and Reconciliation Commission: See Sierra Leone Truth and Reconciliation Commission (n 110) 37-38.

119 The Commission for Reception, Truth and Reconciliation in Timor-Leste (n117) para 84, page 18. See also the Office of the United Nations High Commissioner for Human Rights, Fact Sheet 6/Rev.3, Enforced or Involuntary Disappearances, Geneva: United Nations, July 2009, 3-4.

120 The Commission for Reception, Truth and Reconciliation in Timor-Leste (n 117) para 16 (3).

121 Ibid para 16 (11). See also paras 86-88, page19 and paras 128-132, pages 26-27.

122 The Commission for Reception, Truth and Reconciliation in Timor-Leste, Chega! The Report of the Commission for Reception, Truth and Reconciliation in Timor-Leste (CAVR), Section 7.3 Forced Displacement and Famine (Commission for Reception, Truth and Reconciliation 31 October 2005). See also CAVR, Forced Displacement and Famine, National Public Hearing, 28-29 July 2003, CAVR, 2005. 
loss of access to food crops, livestock, housing, agricultural implements and land'. ${ }^{123}$ For others it resulted in death. In its detailed report on the findings in relation to famine and displacement ${ }^{124}$ the Commission found that,

Death was caused by famine, famine-related diseases, vulnerability to sickness from hunger, fear or exhaustion and a lack of access to medical care. It is likely that more people died from the effects of displacement than from any other violation, while the actual number of deaths is incalculable. ${ }^{125}$

Unfortunately, despite the severe, systematic and extensive nature of these socio-economic rights violations they were not remedied under the reparations programme. Rather, the CAVR felt it had pushed the scope of its mandate as far as was possible in the circumstances and stopped short of seeking remedy for these violations, due to the 'principles of feasibility and prioritisation based on need'. ${ }^{26}$ The result was a reparations programme focused upon and limited to victims of torture, people with mental and physical disabilities and victims of sexual violence. ${ }^{127}$ However, the reparations programme also identified recipients on the basis of vulnerability. Therefore widows and children were targeted. This also meant that for some victims of economic and social rights violations reparations of some kind were given. ${ }^{128}$ The approach though was not one which prioritised victims of economic and social rights violations. Many people who had been made homeless, had suffered starvation, malnutrition and a lack of education were excluded from the programme.

What is significant about the transitional justice process in this case was the explicit human rights framework applied to the economic and social rights violations. In this process these rights violations were framed as such and reference was made to international human rights law. Consequently, socio-economic rights violations were brought in some way to the foreground of transitional justice concerns, although ultimately they were not treated on an equal footing with violations of civil and political rights. Despite an explicit and specific mandate to investigate economic and social rights violations, priority was given in the end to reparations for civil and political rights violations. Of course there are many reasons why this might have been

123 The Commission for Reception, Truth and Reconciliation in Timor-Leste (n 122) Section 7.3.7, para 503(5).

124 Ibid.

125 The Commission for Reception, Truth and Reconciliation in Timor-Leste (n 122) para 503(4).

126 The Commission for Reception, Truth and Reconciliation in Timor-Leste, Chega! The Report of the Commission for Reception, Truth and Reconciliation in Timor-Leste (CAVR), Recommendations Part 11, 12.6 Guiding principles for a reparations programme in Timor-Leste (Commission for Reception, Truth and Reconciliation 31 October 2005) 39-41.

127 Ibid.

128 Reparations can take many forms. In this case for example, school fees were paid, access to rehabilitation and healthcare was given as well as skills training for women. See The Commission for Reception, Truth and Reconciliation in Timor-Leste (n 126) 12.12 Methods, pages 43-45. 
the case, not least the capacity of the CAVR to act and enforce any reparations for such rights violations. However, as Sharp notes, this served to promote a 'hierarchy of rights' and granted de facto impunity to those responsible for 'economic violence.' ${ }^{29}$ On a positive note though, the experiences of the CAVR represent a clear development in mandate of a truth and reconciliation process regarding investigation and reporting of findings of economic and social rights violations.

Overall, the evidence illustrates that truth and reconciliation commissions have the potential to address both direct grave violations of economic and social rights and more structural ongoing violations of these rights, if they are brought to the foreground of the mandate and crucially the focus remains throughout the process. There is a need to build upon the past experiences to date. If we look at the experience of South Africa today it is evident that the legacy of structural injustice still exists. Racial and social divisions remain (although not legally sanctioned), for instance in healthcare, education and housing. ${ }^{130}$ This situation remains despite the enshrinement of economic and social rights in the South African Constitution and substantial jurisprudence concerning socio-economic rights within the constitutional court. An interesting and important question to ask is if violations of economic and social rights had been brought to the foreground of the SATRC, then would the outcome and the impact upon long-term peace and reconciliation in South Africa have been any different?

The experience of the CAVR in Timor-Leste is arguably a more positive development in terms of the recognition of economic and social rights violations as genuine crimes with legal standing which can be investigated and examined within the main body of work of a truth commission and with effective findings. The CAVR process marks the beginning of foregrounding of such rights, even if not seen through to specific remedy or reparations. It signifies a move away from economic and social rights violations as background or contextual information. As such, the work of the CAVR is to be commended and built upon for the future as an example of good practice. In addition, the specialised hearings of the SATRC and the Sierra Leone Truth and Reconciliation Commission are useful in drawing attention to the structural injustices and endemic economic and social rights violations within a regime. Both these methods (and a combination of the two) are markedly useful in documenting evidence of economic and social rights violations during conflict and transition.

$129 \quad$ Sharp (n 17) 795.

130 Although black people are 'free' to access all services and goods that white people are, economically and socially black people remain marginalised. Race and class remain inextricably linked. See Wale. K, Confronting Exclusion: Time for Radical Reconciliation, SA Reconciliation Barometer Survey: 2013 Report (Institute for Justice and Reconciliation 2013) 7; Bertelsmann Stiftung, BTI 2014 - South Africa Country Report (Gütersloh: Bertelsmann Stiftung 2014) 14, 23. 


\section{HOW TO MOVE FORWARD - DEVELOPING TRANSITIONAL JUSTICE AND ADDRESSING REMAINING CHALLENGES}

One of the most difficult challenges facing incorporation of economic and social rights within transitional justice mechanisms is how to design and implement a meaningful and effective reparations programme and the wider question of what should be considered remedy. Is the right to be heard remedy enough? As noted above reparations for violations of socio-economic rights have been lacking, even where transitional justice mechanisms have engaged with such violations as a part of their mandate. The question of reparations goes beyond the remit of this article. Suffice to say that further research is required in this area to explore the nature and form of reparations for economic and social rights violations, including the notion of community rather than individual reparations; non-financial reparations and the relationship between community reparations and the right to development. ${ }^{131}$

A second and related challenge is which transitional justice mechanism to choose and how to delineate boundaries for the scope of the investigation into economic and social rights violations. Of course the choice of mechanism and scope of investigation will be partly subjective to each transition in question and the drivers of that particular conflict, but these choices have implications for the consideration (or not) of such rights violations. The choice of mechanism could limit the extent to which economic and social rights violations are a part of the mandate. The choice of mechanism is also significant in relation to the needs of the local population and grassroots demands for justice (and peace and reconciliation). Local communities often feel that international and legalistic transitional justice mechanisms result in their exclusion or marginalisation from the process. ${ }^{132}$ International efforts are often led by the agenda of external actors rather than by local priorities for justice. An interesting example of local demands for transitional justice in relation to violations of economic and social rights can be seen in Colombia, where local communities have called for a reparations programme to specifically address economic and social rights

131 L. Magarrell, Reparations in Theory and Practice, Reparative Justice Series (International Center for Transitional Justice 2007) at <http://ictransitionaljustice.org/sites/default/files/ICTJ-GlobalReparations-Practice-2007-English.pdf >; Lisa Laplante (n 29); C. Sandoval Villalba, for Redress, Rehabilitation As A Form Of Reparation Under International Law (The Redress Trust 2009); L. McGregor and C. Sandoval Villalba (eds) The Law and Practice of Reparations as a form of Rehabilitation (forthcoming 2014); Naomi Roht-Arriaza, Reparations and Economic, Social, and Cultural Rights (16 November 2012) available at SSRN: <http://ssrn.com/abstract=2177024>; Theo van Boven, The United Nations Basic Principles And Guidelines On The Right To A Remedy And Reparation For Victims Of Gross Violations Of International Human Rights Law And Serious Violations Of International Humanitarian Law (16 Dec 2005) (United Nations Audio Visual Library 2010) at <http://untreaty.un.org/cod/avl/pdf/ha/ga_60-147/ga_60-147_e.pdf> (last accessed 17 June 2013).

132 McEvoy and McGregor (n 43). 
violations including the right to social services and land restitution. ${ }^{133}$ One argument for the inclusion of economic and social rights within transitional justice is therefore, 'where it reflects the needs and priorities of victims. ${ }^{134}$

When establishing the parameters for economic and social rights violations that will be considered as part of the transitional justice process, the question is how does one differentiate between violations that pre-dated the conflict and those that are a consequence of the conflict? As noted, it is questionable that this is even possible or desirable but certainly direct and deliberate grave violations of economic and social rights must be considered. Where possible, existing structural violence in the form of socio-economic violations should also be identified and addressed, especially where these violations are root causes of conflict. As Carranza notes 'gains could be unmade if the conditions that led to or aggravated repression and conflict are left to fester, allowing repression to re-emerge and conflict to reoccur'. ${ }^{2} 35$

Another priority is to recognise the need for inclusion of economic and social rights in order to address violations suffered by women during conflict and transition. The lack of engagement with economic and social rights violations continues to have negative repercussions for the understanding of the abuses suffered by women and girls during conflict, as well as underestimating the prevalence of economic and social rights violations encountered during conflict. To illustrate, the SATRC recognised and admitted that their limited definition of gross human rights violations 'resulted in a blindness to the types of abuse predominantly experienced by women'.136 Commonly women and children are disproportionately affected by violations of socio-economic rights both in peacetime and conflict and as such transitional justice mechanisms need to account for these rights violations if they are to sufficiently address justice for women.

Moreover, this neglect of the experiences of women and other vulnerable groups could result in the transitional justice process actually reasserting the subordination of disadvantaged groups that existed before and during the conflict. The chosen mechanisms are at risk of echoing previously unjust distributions of economic and social rights, for example, where property and land is vested in men, and consolidating pre-existing inequalities 'at personal, social and structural levels'. ${ }^{137}$ Where transitional justice procedures do make special provision for women, such as the special hearings in South Africa and Sierra Leone, the focus tends to be solely on sexual violence rather than on economic and social rights violations affecting

133 N. Summers, 'Colombia’s Victims' Law: Transitional Justice in a Time of Violent Conflict?' (2012) 25 Harvard Human Rights Journal 220; C. Diaz, 'Challenging Impunity from Below: The Contested Ownership of Transitional Justice in Colombia' in McEvoy and McGregor (n 43) 189-215.

134 Waldorf (n 1) 175. See also Carranza (n 18) 322.

135 Carranza (n 18) 329.

136 South African Truth and Reconciliation Commission (n 102) 318 and para 144.

137 E. Stanley, 'The Political Economy of Transitional Justice in Timor-Leste', in McEvoy and McGregor (n 40) 167-187, 185. 
women. Hearing the accounts of all types of violations endured by women would result in a more truthful account of conflict and reveal underlying gender dimensions of conflicts. ${ }^{138}$ Therefore the inclusion of economic and social rights concerns within transitional justice mechanisms will also contribute to a more holistic and inclusive transitional justice process.

Moreover, women are commonly affected by land issues during transitions. For example, they are often excluded from owning land under local custom, which impacts upon their ability to seek restitution following displacement. ${ }^{139}$ Transitional justice mechanisms have not adequately considered how to deal with violations related to land, such as displacement and destruction of property, resulting in violations of the rights to food, health, water, housing and work and in the worst cases loss of life. ${ }^{140}$ The issue of land sits at the intersection between economic and social rights, civil and political rights, international criminal law, international humanitarian law and local custom and domestic law. As such, further research, both theoretical and empirical, is required as to how best to address land issues in transition. ${ }^{141}$

As a further issue to explore, an examination and further discussion of how to address violations of economic and social rights both within transitional justice mechanisms but also in relation to wider peacebuilding is required. This will necessarily entail examining the broader idea of transitional justice. Where do the boundaries lie between transitional justice and peacebuilding? ${ }^{142}$ Certainly, transitional justice is often perceived as a pillar or component of peacebuilding and post-conflict reconciliation. ${ }^{143}$ What are the aims of transitional justice and should a shift from transitional justice to an inclusive process of transformative

138 Schmid (n 5) 6 and 16. Further reading on transitional justice and gender see S. Buckly-Zistel and R. Stanley, Gender in Transitional Justice (Palgrave Macmillan 2012); E. Zinsstag and M. Fineman (Eds), Feminist Perspectives on Transitional Justice: From International and Criminal to Alternative Forms of Justice (Series on Transitional Justice, Intersentia 2013); C. O'Rourke, Gender Politics in Transitional Justice (Routledge 2013).

139 L. Hovil, 'The Nexus between Displacement and Transitional Justice: A Gender-Justice Dimension' in R. Duthie (ed), Transitional Justice and Displacement (International Center for Transitional Justice/Social Science Research Council 2012) 329, 348.

140 As previously noted the Commission for Reception, Truth and Reconciliation in Timor-Leste, experience is a good starting point regarding land and displacement and ESR.

141 Recent articles which examine land and transitional justice include, M. Evans, 'Land, socioeconomic rights and transformative justice' Paper presented at Land Divided: Land and South African Society in 2013, in Comparative Perspective conference, University of Cape Town, 2427 March 2013; O. Zenker, Land Restitution and Transitional Justice in Post-Apartheid South Africa, Max Planck Institute for Social Anthropology Working Paper No.134 (Max Planck Institute for Social Anthropology 2011).

142 There is a question as to whether there is a way to distinguish between economic and social rights violations that should be considered as an element of transitional justice as opposed to being a concern for post-conflict reconstruction. See T. Pasipanodya, 'A Deeper Justice: Economic and Social Justice as Transitional Justice in Nepal' (2008) 2 International Journal of Transitional Justice 378, 390.

143 Schmid (n 5) 8; Laplante (n 1) 347; van Zyl in Laplante (n 1) 333 note 11; Sharp (n 17) 781. 
justice be considered? Whether transitional justice and peacebuilding is viewed as part of the same process or as parallel developments, it is clear that there is potential for impact stemming from the decisions of transitional justice bodies, in terms of remedy and reparations for violations of economic and social rights, upon the future realisation and enjoyment of these rights at both a legal and practical level. Experiences in Liberia, Nepal and Timor-Leste all support the thesis that transitional justice and peacebuilding need to be elements of an integral process. If a peace agreement and/or constitution incorporates economic and social rights ${ }^{144}$ then the transitional justice mechanisms that follow need to consider economic and social rights and the transitional justice body in turn can make recommendations that then seek to promote a framework for the realisation of these rights (both legal and structural). Without this continuity - if all the processes are seen as separate entities then gaps in effectiveness will continue. Of course, it does not necessarily follow that one step will follow from the next. For example, in the case of Nepal, despite adopting a peace agreement with a deep commitment to address economic and social rights ${ }^{145}$ there has been no explicit inclusion to date of these rights in the transitional justice mechanisms set up by the Nepalese government. ${ }^{146}$ Conversely, the recommendations of the Liberian Truth and Reconciliation Commission did call for reform of public institutions to promote good governance and human rights; to reduce poverty; to alleviate illiteracy and to provide equal access to public services. ${ }^{147}$ Although they did not address economic and social rights violations within a human rights framework, these recommendations should have a positive impact upon the enjoyment of these rights in the future. These cases illustrate that the process needs to be looked at as a whole to ensure the optimal protection of economic and social rights.

\section{CONCLUDING REMARKS}

Both prosecutorial justice and restorative justice mechanisms have failed to include economic and social rights as a core concern. As noted, this is in part due to the focus within transitional justice on criminal justice, the historical discourse on the nature of economic and social rights themselves and the non-justiciability arguments regarding them. It is evident that there is a need to redefine ideas of

144 The OHCHR note that 'Constitutions and peace agreements offer further entry points for enshrining protections for economic, social and cultural rights in post-conflict societies' (OHCHR (n 1) para 63).

145 See the Comprehensive Peace Agreement concluded between the Government of Nepal and the Communist Party of Nepal (Maoist), November 21, 2006, sections 7.1.2 and 7.5 Economic and Social Rights including the right to food, health, education, social security. See also The Interim Constitution of Nepal, 2063 (2007).

146 Pasipanodya (n 142) 392; Schmid (n 5) 12.

147 Republic Of Liberia Truth And Reconciliation Commission (n 105) 11-12. 
transitional justice to include a broader conception of justice, which includes both criminal justice and wider social justice. The inclusion of economic and social rights resulting in a more holistic process should make transitional justice mechanisms more effective to the needs of the people. 'Demands for truth' must also include the truth regarding past and existing violations of socio-economic rights. Evidently by bringing such rights violations to the foreground of a truth and reconciliation commission process rather than relegating economic and social rights violations to contextual or background information results in a more 'truthful' account of the conflict and therefore more effective justice, truth and reconciliation. Moreover, transitional justice bodies need to hold those responsible for violations of economic and social rights to account just as it does for violations of civil and political rights. This will include seeking remedy for direct and deliberate acts of violence which violate economic and social rights but also seeking remedy where appropriate for more structural endemic violations which are a result of the ongoing conflict and/or those that act as conflict triggers. ${ }^{148}$ Furthermore, as Schmid notes 'incorporating economic and social rights violations makes the rhetoric of the indivisibility and interdependence of rights a reality.' ${ }^{149}$

The following proposals formulate a minimum starting point for the development of a transitional justice process which addresses economic and social rights violations. In the first instance, the body appointed to deal with transitional justice in a particular State should include members with expertise in the area of economic and social rights. This will improve their capacity to deal with violations of such rights. Furthermore, truth and reconciliation commissions and international courts and tribunals should include within their mandate a definition of human rights violations which includes socio-economic rights. Their mandate should include a capacity to investigate, examine and remedy these violations, including reparations (of some kind). As noted above, the issue of reparations for economic and social rights violations represents a challenge that requires further research. Moreover, if a State has not ratified international treaties regarding economic and social rights ${ }^{150}$ the transitional justice body should recommend that they do so. Furthermore, the bodies should also consider recommendations for wider peacebuilding measures that could assist in the remedy and further protection of economic and social rights, both normative legal measures and practical measures for implementation of such rights. Finally, those involved in transitional justice both practice based and academic researchers should seek to

148 P. Gready, The Era of Transitional Justice - The Aftermath of the Truth and Reconciliation Commission in South Africa and Beyond (Routledge GlassHouse 2011) 215.

149 Schmid (n 5) 19.

150 Inter alia, UN International Covenant on Economic, Social and Cultural Rights (n 53) and Optional Protocol to the International Covenant on Economic, Social and Cultural Rights (adopted 10 December 2008, entered into force 5 May 2013) A/63/435; C.N.869.2009.TREATIES-34 of 11 December 2009. 
gather evidence of best practice and to undertake further research on all aspects of economic and social rights, transitional justice and wider peacebuilding. ${ }^{151}$

If violations of economic and social rights continue to be omitted from or pushed to the background of transitional justice mechanisms, transitional justice cannot and will not be truly effective. Progress can be made if those working in the field begin by accepting the premise that if the aim of transitional justice is to achieve justice for human rights violations as an element of sustainable peace, there is a need to address grave and deliberate violations of both economic and social rights and civil and political rights. ${ }^{152}$ There is also a need to address where possible violations of economic and social rights which are systematic and structural. ${ }^{153}$ As a starting point it is evident that for transitional justice to be effective it needs to take into account any violations of economic and social rights that are prevalent during the time period established by the transitional justice mechanism as within their mandate. Moreover, it is important to note that the wider process of peacebuilding will also need to address these structural violations if peace is to be achieved.

Human rights cannot make people trust one another or even like one another - this is the process of reconciliation. However, human rights can set minimum standards of humanity to follow in societies that are in transition from conflict and repression to peace - protections to ensure people feel secure and safe and to allow them that security to start the process of reconciliation. Holding to account those who are responsible for grave violations of economic and social rights and realising these rights as a part of transitional justice and wider peacebuilding are therefore essential to any effective reconciliation process. Transitional justice should be concerned with aiding transition from violence to peace not solely through criminal justice but also through realisation of substantive social justice. Ultimately, there is a need to foreground violations of economic and social rights within transitional justice. Only then can it be truly effective.

$151 \quad$ For example further comparative analysis could be undertaken looking at the practice of truth commissions with regards to economic and social rights. Likewise, further research on the links between economic and social rights, transitional justice and peacebuilding is required.

152 Sharp (n 17) notes that this will include consideration and reorientation of the 'transition' in transitional justice from a narrow concern with transition to democracy to a broader concern with transition to positive peace and freedom from structural violence.

153 See UN Human Rights Council, Report of the Special Rapporteur on the promotion of truth, justice, reparation and guarantees of non-recurrence, Pablo de Greiff (9 August 2012) A/HRC/21/46 paras 50-51. 